\title{
6. Improving West African rice production with agricultural water management strategies
}

\author{
Pamela G. Katic \\ International Water Management Institute, Ghana
}

The populations of West African countries continue to grow at rates exceeding three per cent per year. The international food price spike of 2008 focused attention on the risks to national security and livelihoods associated with importing significant quantities of food; and government and donor investment strategies now focus on ensuring national food security. Since rice is a key staple crop in the region, increasing rice production in a profitable way is critical to food security and sustained economic growth.

Over the last 20 years, increases in rice production have generally been obtained by putting more land under cultivation. As pressure on land intensifies, however, the results are a dramatic decline in soil fertility, increasingly degraded natural resources and increasing conflicts over land use. In this context and as observed worldwide, water-management interventions are key to the intensification of rice production. The importance of irrigation or water control in enabling a 'green revolution' has been underlined in many continental, regional and national strategic policy documents.

Diverse typologies of rice-irrigation systems exist in West Africa, which can be categorised into two broad classes: conventional systems and emerging systems. The conventional systems are mainly initiated and developed by governments and nongovernmental organisations (NGOs), or are developed by communities or individuals over a number of years. Conventional systems include public surface irrigation systems and small reservoirs. The emerging systems are those irrigation systems initiated and developed by private entrepreneurs and farmers, either autonomously or with little support from the government and/ or NGOs. The emerging systems include river/stream lifting or pumping-based irrigation systems, public/private partnership-based systems, lowland/inland valley rice water capture systems, and private small-reservoir systems.

In order to understand the impact of alternative water-management options and policy interventions on the profitability of rice production, this study analysed farm household data from three donor-funded project surveys in 
three West African countries. ${ }^{1}$ The data was collected in two sites in Ghana, one in Burkina Faso and one in Niger; and looked at detailed rice-production budgets of small-scale farmers. The farmers interviewed were classified into three water management systems: irrigation (public scheme), supplemented rain-fed (rainfall aided by autonomously sourced water supplies) and purely rain fed (Katic et al. 2013).

Once the surveys were completed, the results were collected and analysed with a policy analysis matrix (PAM) $)^{2}$ in order to answer three key questions:

1. What is the impact of water management interventions on rice farmers' income?

2. Is local irrigated rice price competitive against imported rice without additional public policy interventions?

3. What are the major determinants of local rice profitability in West Africa?

\section{Impact of water management interventions on rice farmers' income}

The analysis revealed that water-management interventions may or may not increase rice farmers' income in the sites studied. Our result is in contrast to previous studies that have found (under different assumptions on labour costs and local prices) that rice production always breaks even, or earns positive profits in the region (Coronel and Lançon 2008; Seini 2002; Seini and Asante 1998).

On one hand, water management raises rice revenues by increasing yields. On the other hand, these farming systems require a higher amount of labour per unit of land, increasing production costs. While in the Ghanaian sites, the cost of implementing water management (both supplemented rain-fed and irrigated systems) outweighs modest increases in rice yields valued at low prices; in Burkina Faso, lower wage rates and a higher price for local rice mean that the value of greater yields is more than sufficient to cover the costs of irrigation.

\footnotetext{
1 'Lowland paddy fields development/Disseminating lowland rice cultivation in inland valleys in West Africa' and 'Assessing the impact of Sawah development on rice farmers in the Ashanti region, Ghana' both funded by the Government of Japan, Ministry of Foreign Affairs; and WAIPRO (West African Irrigation Project) funded by USAID.

2 A PAM is an analytical framework that is frequently used to advise agricultural policy in the context of comparative advantage and private competitiveness. It consists of a two-way accounting matrix measuring revenues, costs and the derived profits at private (actual) and social (efficiency) prices.
} 


\section{Comparative advantage of local rice production}

The data revealed that internationally traded rice varieties are higher quality than locally produced rice. Thus, with or without pricing policies, local rice cannot compete with imported rice on price because they are different products.

The main public policy in place in the region that affects the profitability of local rice production is an import tariff that inflates the price of competing Asian rice varieties. Although imported rice is more expensive than local rice, even if no tariff were imposed, most local consumers still buy it due to its nonprice attributes (absence of stone, less broken rice, uniformity and appearance). Even the lowest quality imported rice (Thai 25 per cent broken) is still better than the rice produced in all study areas.

The price gap between imported and local rice confirms that the two categories of product are not considered as substitutes by consumers. Thus, there are two different markets and the popular import tariffs have a weak additional demand impact on the market for local rice. Just because local rice is cheaper, it does not mean it is more competitive because the two products are not directly substitutable. This result suggests that there is a huge opportunity for the local industry to upgrade rice quality via effective policies/investments. This opportunity is greater for irrigated rice farms because the higher yields realised imply that the quality upgrade is applied to a greater production level.

\section{Determinants of local rice profitability}

The analysis revealed that the major factors influencing rice profitability in West Africa are labour costs, world rice prices and local rice quality. In addition, exogenous or policy-induced changes in these factors have a greater impact on rice produced under some form of water management.

\section{Labour costs}

Results suggest that profits are sensitive to labour costs. The analysed sites comprised small-scale farms where most labour is family based, whose opportunity cost is likely to be lower than the market wage. Rice production becomes a profitable venture when labour is valued at a rate lower than two-thirds of the market wage (or the quantity of labour employed falls below two-thirds of its original value). When comparing rain-fed fields with those under some form of water management, profits are more responsive to labour costs in the latter, simply because these systems are currently more labour intensive. Thus, efforts to increase the mechanisation levels of 
rice production systems in the region are especially needed to reduce the intensity of on-farm labour use in irrigated farms and boost yields even further by diminishing harvesting and post-harvesting losses.

\section{World prices}

Sensitivity results reveal that large variations in world rice prices would substantially impact the local rice industry. A fall in the price of the higher quality international varieties would reduce demand for local production and, in turn, reduce the price local farmers receive. In fact, if prices fell to pre-2008 levels and technology was unchanged, rice production throughout the whole region would become unprofitable for farmers. What is more interesting, even if local rice is upgraded to a 25-per-cent-broken quality equivalent, it will be less costly to rely on imported rice than to produce it internally. In this case, however, irrigated systems would be much more resilient to the competition of cheaper imported rice than rain-fed production because they attain higher yields.

\section{Rice quality}

The data reveals rice quality is as key to farm profitability as yields. The low quality of rice obtained after milling is explained by a combination of factors that include poor seed variety, lack of soil and water management, low input use, inappropriate farming, harvesting and post-harvesting techniques, and milling technology. The study results show that there is potential to raise private profits with quality improvements (profits would be over US $\$ 400 /$ hectare if local rice is upgraded to a 25-per-cent-broken quality equivalent). In particular, irrigated systems benefit more from rice-quality upgrades because the effect on profits is complemented with greater yields. As a result, policies to improve both physical and quality loss should be complementary to reap the greatest potential from this use of land.

\section{Policy implications}

Overall, the results suggest that while trade policies are not effective in boosting local rice production in West Africa, investment policies, such as irrigation developments, have potential to raise the returns to rice producers. The results also suggest that to simultaneously enhance farm incomes, contribute to national economic growth and increase food security, water management must be complemented with further farm interventions to reduce quantity and quality losses. 
Pamela $G$ Katic is a Researcher in economics at the International Water Management Institute (IWMI), Accra, Ghana. After receiving a $\mathrm{PhD}$ in economics from The Australian National University, she was appointed PostDoctoral Fellow in economics at IWMI, and later became a Researcher. In this position, she has gained experience assessing the constraints and opportunities of innovative land-water management technologies in West Africa. This article is based on an original piece of research published in Volume 1 of the Elsevier journal Water Resources and Economics: 'Rice and irrigation in West Africa: achieving food security with agricultural water management strategies'.

\section{References}

Coronel, C. and Lançon, F., 2008. 'Study and training on the Ghanaian commodity chain (final report)', IRAM (Institut de recherches et d'applications des méthodes de développement).

Katic, P.G., Namara, R.E., Hope, L., Owusu, E. and Fujii, H., 2013. 'Rice and irrigation in West Africa: achieving food security with agricultural water management strategies', Water Resources and Economics 1:75-92.

Seini, A.W., 2002. 'Agricultural growth and competitiveness under policy reforms in Ghana', Technical Publication no. 61, ISSER (Institute of Statistical, Social and Economic Research), University of Ghana, Accra.

and Asante, F.A., 1998. 'Rice production systems in Ghana - a policy analysis matrix (PAM) assessment', Project R6688: Improving the competitiveness and marketability of locally-produced rice in Ghana, Crop Post Harvest Programme, DFID (Department for International Development), Accra. 
This text taken from Global Water: Issues and Insights by R. Quentin Grafton, Paul Wyrwoll, Chris White and David Allendes, published May 2014 by ANU Press, The Australian National University, Canberra, Australia. 